\title{
Structure-Based Design of Flavonoid Compounds As a New Class of Small-Molecule Inhibitors of the Anti-apoptotic Bcl-2 Proteinŝ
}

\author{
Guozhi Tang $^{+}, \mathrm{Ke} \mathrm{Ding}^{+}$, Zaneta Nikolovska-Coleska ${ }^{+}$, Chao-Yie Yang ${ }^{+}$, Su Qiu ${ }^{+}$, Sanjeev \\ Shangary $^{+}$, Renxiao Wang ${ }^{+}$, Jie Guo ${ }^{+}$, Wei Gao ${ }^{+}$, Jennifer Meagher ${ }^{\exists}$, Jeanne Stuckey ${ }^{\exists}$, \\ Krzysztof Krajewski ${ }^{\#}$, Sheng Jiang ${ }^{\#}$, Peter P. Roller\#, and Shaomeng Wang ${ }^{+}$ \\ + Comprehensive Cancer Center and Departments of Internal Medicine, Pharmacology and Medicinal \\ Chemistry \\ $\exists$ Life Sciences Institute, University of Michigan, 1500 E. Medical Center Drive, Ann Arbor, MI 48109, USA \\ \#Laboratory of Medicinal Chemistry, National Cancer Institute-Frederick, National Institutes of Health, \\ Frederick, Maryland 21702;
}

\begin{abstract}
Structure-based strategy was employed to design flavonoid compounds to mimic the Bim BH3 peptide as a new class of inhibitors of the anti-apoptotic Bcl-2 proteins. The most potent compound, 4 (BI-33), binds to Bcl-2 and Mcl-1 with Ki values of 17 and $18 \mathrm{nM}$, respectively. Compound 4 inhibits cell growth in the MDA-MB-231 breast cancer cell line with an $\mathrm{IC}_{50}$ value of $110 \mathrm{nM}$ and effectively induces apoptosis.
\end{abstract}

\begin{abstract}
The $\mathrm{Bcl}-2$ family proteins are central regulators of apoptosis and comprise anti-apoptotic proteins such as Bcl-2, Bcl-xL and Mcl-1 and pro-apoptotic proteins such as Bak, Bax, Bim, Bid and Bad. ${ }^{1-4}$ Although the precise molecular mechanism by which these Bcl-2 proteins regulate apoptosis is still under intensive investigation ${ }^{5,6}$, it is very clear that the anti-apoptotic proteins and the pro-apoptotic proteins modulate their opposing functions through heterodimerization. Experimental three-dimensional structures of Bcl-2, Bcl-xL and Mcl-1 show that these proteins form a well-defined, hydrophobic surface binding groove, known as the Bcl-2 homology domain 3 (BH3) binding groove, into which these pro-apoptotic proteins bind. ${ }^{7-11}$ It has been hypothesized that non-peptide, small-molecule inhibitors that bind in the $\mathrm{BH} 3$ binding groove in $\mathrm{Bcl}-2, \mathrm{Bcl}-\mathrm{xL}$ and $\mathrm{Mcl}-1$ can block the heterodimerization between the anti-apoptotic and pro-apopototic Bcl-2 members. ${ }^{12-19}$ Since cancer cells often express high levels of one or more of these anti-apoptotic Bcl-2 proteins, such small-molecule inhibitors can induce apoptosis on their own and/or sensitize cancer cells for apoptosis induction by antagonism of these anti-apoptotic Bcl-2 proteins. ${ }^{2}$ Design of inhibitors of $\mathrm{Bcl}-2$, Bcl-xL and Mcl-1 is being intensely pursued as a novel strategy for the development of new anticancer drugs. ${ }^{12-19}$ The development of potent, druglike, non-peptide small-molecule inhibitors to block these $\mathrm{Bcl}-2$ protein-protein interactions remains one of the most challenging tasks in modern drug discovery and medicinal chemistry.
\end{abstract}

\footnotetext{
Supporting Information: An experimental section including information on the synthesis and chemical data for compounds 2-6, molecular modeling methods and results for $\mathbf{2}$ and $\mathbf{4}$, the experimental procedure for the fluorescence polarization-based binding assays for Bcl-2, Bcl-xL and Mcl-1, details on the cellular growth inhibition and apoptosis assays is available free of charge via the Internet at http://pubs.acs.org.
} 
In this report, we wish to present our structure-based design of a potent, cell-permeable, nonpeptidic small-molecule that mimics the key binding residues in the $\mathrm{Bim} \mathrm{BH} 3$ peptide and binds to Bcl-2 and Mcl-1 proteins with high affinities.

Through structure-based database screening, we discovered previously 18,20 that $\mathbf{1}$, a natural product isolated from seeds and roots of the cotton plant, is a fairly potent inhibitor of Bcl-2, Bcl-xL and Mcl-1. Compound 1 binds to Bcl-2, Bcl-xL and Mcl-1 with $\mathrm{K}_{\mathrm{i}} \mathrm{values}$ of 320, 480, and $180 \mathrm{nM}$ respectively, determined by competitive fluorescence polarization-based (FPbased) binding assays. ${ }^{18}$ Compound $\mathbf{1}$, currently in clinical trials as a single, oral agent for the treatment of human cancers, has demonstrated antitumor activity and manageable toxicity. 21 It therefore is a promising lead compound for the design of potent, non-peptidic smallmolecule inhibitors targeting the anti-apoptotic Bcl-2 proteins.

Based upon our predicted binding model (Figure 2a), 1 forms a hydrogen bonding network with residues Arg146 and Asn143 in Bcl-2 through the aldehyde group and its adjacent hydroxyl group on one of the naphthalene rings. This mimics the hydrogen bonding network formed by Asp99 and Asn102 in Bim and Arg146 and Asn143 in Bcl-2 (Figure 2b). The hydrophobic isopropyl group on the same naphthalene ring inserts into a hydrophobic pocket in Bcl-2, in part mimicking the Phe101 in the Bim peptide. The other naphthalene ring interacts with Bcl-2 primarily through hydrophobic contacts, mimicking Ile97 in the Bim peptide. Thus this predicted binding model provides a structural basis for the design of novel small-molecule inhibitors of Bcl-2.

Our modeling suggested that one half of compound $\mathbf{1}$ forms an extensive hydrogen bonding network and also has hydrophobic interactions with Bcl-2. We searched for structures that would mimic the interactions mediated by the half of compound $\mathbf{1}$ with $\mathrm{Bcl}-2$. Among a number of templates we have investigated, compound $\mathbf{2}$ was predicted by modeling to mimic one half of compound 1 closely in its interaction with Bcl-2 (Figure 2c).

Compound 2 was synthesized (Scheme I) and was found to bind to Bcl-2 with a $\mathrm{K}_{\mathrm{i}} \mathrm{value}$ of $730 \mathrm{nM}$ (Figure 3) in our FP-based binding assay (Supporting Information). Although it is 4times less potent than $\mathbf{1}$, it has a significant affinity for Bcl-2. Compound $\mathbf{2}$ contains a flavonoid core structure found in many natural products, has well balanced hydrophobic and hydrophilic properties and is thus a promising new template for further optimization.

Based upon our modeling (Figure $2 \mathrm{~b}$ ), the Bim BH3 peptide interacts primarily with Bcl-2 through 4 hydrophobic residues (Ile90, Leu94, Ile97 and Phe101) and one negatively charged Asp99 residue. Modeling also shows that compound 2 binds to Bcl- 2 by mimicking the Phe101, Ile97 and Asp99 in the Bim peptide but lacks the interactions of Ile90 and Leu94 in the Bim peptide with Bcl-2. This suggests that capture of these additional hydrophobic interactions should significantly improve the binding affinity of compound $\mathbf{2}$. Our modeling indicates that the isobutyl and the methyl groups in compound 2 can mimic Ile90 and Leu94 residues in the Bim peptide, two hydrophobic residues separated by a single helical turn in the Bim BH3 peptide. We have thus investigated if the basis core structure of compound 2 can be used as a general helical mimic to capture the interactions by Ile 90 and Leu 94 residues in the Bim peptide with Bcl-2. This led to the design of template 3 (Figure 1), which contains two identical isoflavonoid moieties of $\mathbf{2}$, tethered through a linker.

Modeling showed that a phenyl group has the appropriate geometry to tether these two flavonoid moieties together through its 1,4 positions to mimic Ile90, Leu94, Ile97 and Phe101 in the Bim peptide (Figure 2d) and this led to the design of compound 4 (Figure 1). In our model, compound 4 also forms an extensive hydrogen bonding network with Arg 146 and Asn143 in Bcl-2 through one of the flavonoid moieties, thus mimicking the interactions of Asp99 in Bim with Bcl-2 (Figure 3). In addition, an additional hydrogen bond is formed 
between one hydroxyl group on the other flavonoid moiety and Val133 in Bcl-2. The model also showed that compound $\mathbf{4}$ mimics these key residues in the Bim BH3 and predicted that compound 4 should achieve a higher affinity to Bcl-2 than the initial lead compound 2 . Indeed, compound 4 was determined to bind to Bcl-2 with a $\mathrm{K}_{\mathrm{i}}$ value of $17 \mathrm{nM}$ (Figure 3) in our FPbased binding assay, which is 43 -times more potent than $\mathbf{2}$. Of note, $\mathbf{4}$ is also 10 -times more potent than $\mathbf{1}$.

Our modeling predicted that the phenyl group in compound $\mathbf{4}$ functions as a linker and the hydroxyl groups in $\mathbf{4}$ play a critical role through formation of an extensive hydrogen bonding network with Bcl-2. To test these predictions, we designed and synthesized compounds $\mathbf{5}$ and 6 and evaluated their binding to Bcl-2. Compound 5 binds to Bcl-2 with a $\mathrm{K}_{\mathrm{i}}$ value of $340 \mathrm{nM}$ and is only twice as potent as compound $\mathbf{2}$, indicating that the additional phenyl ring in compound $\mathbf{5}$ primarily functions as a tethering group. As predicted, compound $\mathbf{6}$ with all these 6 hydroxyl groups methylated shows no appreciable binding to Bcl-2 at concentrations as high as $50 \mu \mathrm{M}$.

We found with an FP-based competitive binding assay that compound 4 binds to Bcl-xL with a Ki value of $1.2 \mu \mathrm{M}$. Hence, compound 4 binds to Bcl-2 with an affinity 70 -times more potent than to Bcl-xL.

Although Bcl-2 and Bcl-xL have been the primary focus for the design of small-molecule inhibitors that target the anti-apoptotic Bcl-2 proteins, recent studies have demonstrated that Mcl-1 plays a critical role in apoptosis resistance of cancer cells and Mcl-1 has become a highly attractive target for anticancer drug design. ${ }^{22}$ We have therefore evaluated the binding affinities of our designed compounds to Mcl-1. As can be seen in Figure 4, compound 4 binds to Mcl-1 with a $\mathrm{K}_{\mathrm{i}}$ value of $18 \mathrm{nM}$. In comparison, compounds $\mathbf{1}, \mathbf{2}$ and $\mathbf{5}$ bind to Mcl-1 with $\mathrm{K}_{\mathrm{i}}$ values of 180,1690 , and $400 \mathrm{nM}$, respectively, while compound $\mathbf{6}$ shows no appreciable binding at concentrations as high as $50 \mu \mathrm{M}$.

The recent publication of crystal structures ${ }^{11}$ of Mcl-1 provides an opportunity to examine computationally the docking of 4 to $\mathrm{Mcl}-1$ and thus to identify the structural basis for this high affinity binding. Our predicted binding model for $\mathbf{4}$ in the complex with Mcl-1 shows that in its interaction with Mcl-1 it mimics Ile90, Leu94, Ile97, Phe101 and Asp99 in the Bim BH3 peptide (Figure 5). The predicted binding models for compound 4 to $\mathrm{Mcl}-1$ and $\mathrm{Bcl}-2$ are similar but not identical, likely due to structural differences between these two proteins. From our predicted binding models, it is also clear that compound $\mathbf{4}$ can be further optimized to improve its binding to both $\mathrm{Bcl}-2$ and $\mathrm{Mcl}-1$ proteins.

One major advantage of non-peptide, small-molecule BH3 mimetics over peptide-based inhibitors is their superior cell permeability. We have therefore tested our new non-peptide BH3 mimetics for their ability to inhibit cell growth in cancer cell lines with high levels of Bcl-2, Bcl-xL and Mcl-1 proteins. The cell growth inhibition of these compounds in the MDAMB-231 (2LMP) breast cancer cell line is shown in Figure 6.

Consistent with its high binding affinity to Bcl-2 and Mcl-1, compound $\mathbf{4}$ is a potent cell growth inhibitor, achieving an $\mathrm{IC}_{50}$ value of $110 \mathrm{nM}$ in this assay. In direct comparison, compound $\mathbf{4}$ is 17-times more potent than $\mathbf{1}$ and 280-times more potent than our initial lead compound 2 in inhibition of cell growth. Significantly, the potencies of these inhibitors in cell growth inhibition in the MDA-MB-231 breast cancer cell line positively correlate with their binding affinities to Bcl-2 and Mcl-1 proteins. Furthermore, compound 4 was found to be at least 10times less potent in normal prostate epithelial and WI-38 normal fibroblast cells with much lower levels of Bcl-2 and Mcl-1 proteins (Supporting Information). Hence, compound 4 displays a good selectivity for cancer cells with high levels of Bcl-2 and Mcl-1 proteins over normal cells. 
We evaluated compounds $\mathbf{4}$ and $\mathbf{5}$ for their ability to induce apoptosis in the MDA-MB-231 cell line using Annexin-V and propium iodide (PI) double staining by flow cytometry. The results are shown in Figure 7. As can be seen, compound $\mathbf{4}$ is very effective in induction of apoptosis in a dose-dependent manner. Treatment of the MDA-MB-231 cells by 0.5 and 1 $\mu \mathrm{M}$ of 4 for 3 days results in $24.5 \%$ and $64.4 \%$ of apoptotic cells (early + late), as compared to $7.2 \%$ of apoptotic cells in an untreated control. Compound 5 at $1 \mu \mathrm{M}$ for 3 days has little effect in apoptosis induction as compared to untreated control. This is consistent with its much weaker binding affinity to both Bcl-2 and Mcl-1 as compared to $\mathbf{4}$ and its modest activity in inhibition of cell growth.

Finally, we tested compounds $\mathbf{4}$ and $\mathbf{5}$ for their ability to induce cell death in the MDA-MB-231 cell line using the trypan blue exclusion assay (Figure 8). As can be seen, compound 4 effectively induces cell death in a dose- and time-dependent manner at concentrations as low as $100 \mathrm{nM}$ and at the 24-hour time-point, whereas compound $\mathbf{5}$ is much less potent.

The synthesis for compounds $\mathbf{2 , 4 , 5}$ and $\mathbf{6}$ is outlined in Scheme I. Briefly, commercially available 3,4,5-trimethoxyphenol was subjected to Friedel-Crafts acylation under the presence of $\mathrm{BF}_{3} \cdot \mathrm{Et}_{2} \mathrm{O}$ to give isobutyrophenone 7 . Subsequent reduction of the ketone group by triethylsilane in TFA afforded phenol 8. A similar Friedel-Crafts reaction was carried out to introduce the acetyl group. The obtained acetophenol 9 was converted to flavonoid methyl ether 10 in three steps without purification of intermediates. The product of O-acetylation of 9 by acetic anhydride in pyridine was dissolved in anhydrous DMF and added to a suspension of $\mathrm{NaH}$ in DMF. The crude product of Baker-Venkataraman rearrangement ${ }^{23}$ readily gave $\mathbf{1 0}$ upon acid treatment. Demethylation of $\mathbf{1 0}$ with excess BBr3 afforded flavone $\mathbf{2}$. For the synthesis of designed compound $\mathbf{4}$, compound $\mathbf{8}$ was treated with $\mathrm{I}_{2}$ in the presence of $\mathrm{CF}_{3} \mathrm{CO}_{2} \mathrm{Ag}$ to give iodide 11, which was subjected to Suzuki coupling with 1,4phenylenebisboronic acid to give methyl ether $\mathbf{6}$. All six O-methyl groups were successfully removed to give crude isoflavone 4 , which was purified by recrytallization from acetone. Isoflavone $\mathbf{5}$ was also synthesized in a similar manner as $\mathbf{4}$, except that phenylboronic acid was used in Suzuki coupling.

In summary, we have designed and synthesized compound $\mathbf{4}$ which mimics the key binding residues in the Bim BH3 peptide in the interaction with Bcl-2. Compound $\mathbf{4}$, which was named as BI-33, binds to Bcl-2 and Mcl-1 proteins with $\mathrm{K}_{\mathrm{i}}$ values of $17 \mathrm{nM}$ and $18 \mathrm{nM}$, respectively, and has a relatively weak affinity to $\mathrm{Bcl}-\mathrm{xL}$. Compound $\mathbf{4}$ is potent in inhibition of cell growth in the MDA-MB-231 breast cancer cell line with high levels of Bcl-2 and Mcl-1 proteins and effectively induces apoptosis in a dose-dependent manner in the MDA-MB-231 cell line. Of significance, compound $\mathbf{4}$ has a novel chemical scaffold that is different from any known smallmolecule inhibitors of the anti-apoptotic Bcl-2 protein and represents a new class of smallmolecule inhibitors targeting the anti-apoptotic $\mathrm{Bcl}-2$ proteins. Taken together, our data indicate that compound $\mathbf{4}$ is a potent and cell-permeable small-molecule BH3 mimetic. Extensive in vitro and in vivo studies are in progress to elucidate further the molecular mechanism of action of compound $\mathbf{4}$ for apoptosis induction and to ascertain its therapeutic potential, and the results will be reported in due course. The study reported here demonstrates that a structure-based strategy is effective for the design of truly novel, potent, drug-like, nonpeptide small-molecule inhibitors that target protein-protein interactions.

\section{Supplementary Material}

Refer to Web version on PubMed Central for supplementary material. 


\section{Acknowledgement}

We are grateful for the financial support from the National Cancer Institute, National Institutes of Health (U19CA113317), the Department of Defense Breast Cancer Program (BC0009140), the Department of Defense Prostate Cancer Program (PC040537), the Prostate Cancer Foundation, the Breast Cancer Research Foundation, the Susan G. Komen Foundation, Ascenta Therapeutics, Inc. and the Intramural Research Program of the National Institutes of Health from the National Cancer Institute, Center for Cancer Research.

\section{References}

1. Adams JM, Cory S. The Bcl-2 protein family: arbiters of cell survival. Science 1998;281:1322-1326. [PubMed: 9735050]

2. Reed JC. Bcl-2 family proteins: strategies for overcoming chemoresistance in cancer. Advances in Pharmacology 1997;41:501-553. [PubMed: 9204157]

3. Chao DT, Korsmeyer SJ. Bcl-2 family: regulators of cell death. Annu. Rev. Immunol 1998;16:395419. [PubMed: 9597135]

4. Minn AJ, Swain RE, Ma A, Thompson CB. Recent progress on the regulation of apoptosis by bcl-2 family members. Advances in Immunology 1998;70:245-279. [PubMed: 9755339]

5. Kim H, Rafiuddin-Shah M, Tu HC, Jeffers JR, Zambetti GP, Hsieh JJ, Cheng EH. Nat Cell Biol 2006;8:1348-58. [PubMed: 17115033]

6. Willis SN, Fletcher JI, Kaufmann T, van Delft MF, Chen L, Czabotar PE, Ierino H, Lee EF, Fairlie WD, Bouillet P, Strasser A, Kluck RM, Adams JM, Huang DC. Apoptosis initiated when BH3 ligands engage multiple Bcl-2 homologs, not Bax or Bak. Science 2007;315:856-9. [PubMed: 17289999]

7. Petros AM, Medek A, Nettesheim DG, Kim DH, Yoon HS, Swift K, Matayoshi ED, Oltersdorf T, Fesik SW. Solution structure of the antiapoptotic protein Bcl-2. Proc. Natl. Acad. Sci. USA 2001;98:3012-3017. [PubMed: 11248023]

8. Sattler M, Liang H, Nettesheim D, Meadows RP, Harlan JE, Eberstadt M, Yoon HS, Shuker SB, Chang BS, Minn AJ, Thompson CB, Fesik SW. Structure of Bcl-xL-Bak peptide complex: recognition between regulators of apoptosis. Science 1997;275:983-986. [PubMed: 9020082]

9. Petros AM, Nettesheim DG, Wang Y, Olejniczak ET, Meadows RP, Mack J, Swift K, Matayoshi ED, Zhang H, Thompson CB, Fesik SW. Rationale for Bcl-xL/Bad peptide complex formation from structure, mutagenesis, and biophysical studies. Protein Sci 2000;9:2528-2534. [PubMed: 11206074]

10. Wang JL, Liu D, Zhang ZJ, Shan S, Han X, Srinivasula SM, Croce CM, Alnemri ES, Huang Z. Structure-based discovery of an organic compound that binds Bcl-2 protein and induces apoptosis of tumor cells. Proc Natl Acad Sci U S A 2000;97:7124-7129. [PubMed: 10860979]

11. Czabotar PE, Lee EF, van Delft MF, Day CL, Smith BJ, Huang DC, Fairlie WD, Hinds MG, Colman PM. Proc Natl Acad Sci U S A. 2007

12. Degterev A, Lugovskoy A, Cardone M, Mulley B, Wagner G, Mitchison T, Yuan J. Identification of small-molecule inhibitors of interaction between the BH3 domain and Bcl-xL. Nat Cell Biol 2001;3:173-182. [PubMed: 11175750]

13. Tzung SP, Kim KM, Basanez G, Giedt CD, Simon J, Zimmerberg J, Zhang KY, Hockenbery DM. Antimycin A mimics a cell-death-inducing Bcl-2 homology domain 3. Nat Cell Biol 2001;3:18391. [PubMed: 11175751]

14. Enyedy IJ, Ling Y, Nacro K, Tomita Y, Wu X, Cao Y, Guo R, Li B, Zhu X, Huang Y, Long YQ, Roller PP, Yang D, Wang S. Discovery of small-molecule inhibitors of Bcl-2 through structurebased computer screening. J. Med. Chem 2001;44:4313-4324. [PubMed: 11728179]

15. Kitada S, Leone M, Sareth S, Zhai D, Reed JC, Pellecchia M. Discovery, characterization, and structure-activity relationships studies of proapoptotic polyphenols targeting B-Cell lymphocyte/ leukemia-2 proteins. J. Med. Chem 2003;46:4259-4264. [PubMed: 13678404]

16. Oltersdorf T, Elmore SW, Shoemaker AR, Armstrong RC, Augeri DJ, Belli BA, Bruncko M, Deckwerth TL, Dinges J, Hajduk PJ, Joseph MK, Kitada S, Korsmeyer SJ, Kunzer AR, Letai A, Li C, Mitten MJ, Nettesheim DG, Ng S, Nimmer PM, O'Connor JM, Oleksijew A, Petros AM, Reed JC, Shen W, Tahir SK, Thompson CB, Tomaselli KJ, Wang B, Wendt MD, Zhang H, Fesik SW, Rosenberg SH. An inhibitor of Bcl-2 family proteins induces regression of solid tumours. Nature 2005;435:677-81. [PubMed: 15902208] 
17. Petros AM, Dinges J, Augeri DJ, Baumeister SA, Betebenner DA, Bures MG, Elmore SW, Hajduk PJ, Joseph MK, Landis SK, Nettesheim DG, Rosenberg SH, Shen W, Thomas S, Wang X, Zanze I, Zhang H, Fesik SW. Discovery of a potent inhibitor of the antiapoptotic protein Bcl-xL from NMR and parallel synthesis, Discovery of a potent inhibitor of the antiapoptotic protein Bcl-xL from NMR and parallel synthesis. J. Med. Chem 2006;49:656-63. [PubMed: 16420051]

18. Wang G, Nikolovska-Coleska Z, Yang C-Y, Wang R, Tang G, Guo J, Shangary S, Qiu S, Gao W, Yang D, Meagher J, Stuckey J, Krajewski K, Jiang S, Roller PP, Abaan HO, Tomita Y, Wang S. Structure-Based Design of Potent Small-Molecule Inhibitors of Anti-Apoptotic Bcl-2 Proteins. J. Med. Chem 2006;49:6139-6142. [PubMed: 17034116]

19. Tang G, Yang C-Y, Nikolovska-Coleska Z, Guo J, Qiu S, Wang R, Gao W, Wang G, Stuckey J, Krajewski K, Jiang S, Roller PP, Wang S. Pyrogallol-Based Molecules as Potent Inhibitors of the Antiapoptotic Bcl-2 Proteins. J. Med. Chem. 2007

20. WangSYangDSmall Molecule Antagonists of Bcl-2 family proteinsUS patent application series \# 200300089242002May 30

21. Saleh, M.; Pitot, H.; Hartung, J.; Holmlund, J.; Albert LoBuglio, A.; Forero, A. Phase I trial of AT-101, an orally bioavailable inhibitor of Bcl-2, in patients with advanced malignancies, The 2005 AACRNCIEORTC International Conference on Molecular Targets and Cancer Therapeutics: Discovery, Biology, and Clinical Applications, Abstract \#C89; November 14-18, 2005;

22. van Delft MF, Wei AH, Mason KD, Vandenberg CJ, Chen L, Czabotar PE, Willis SN, Scott CL, Day CL, Cory S, Adams JM, Roberts AW, Huang DC. The BH3 mimetic ABT-737 targets selective Bcl-2 proteins and efficiently induces apoptosis via Bak/Bax if Mcl-1 is neutralized. Cancer Cell 2006;10:389-99. [PubMed: 17097561]

23. Hirao I, Yamaguchi M, Hamada M. A convenient synthesis of 2- and 2,3-substituted 4H-chromen-4ones. Synthesis 1984;12:1076-8. 

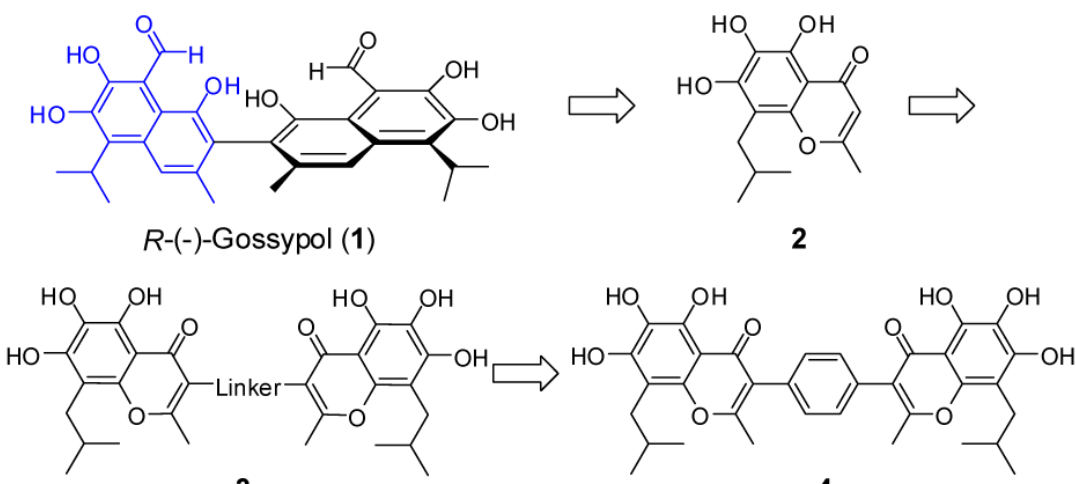

3

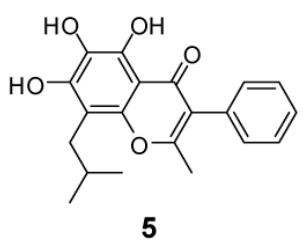

4

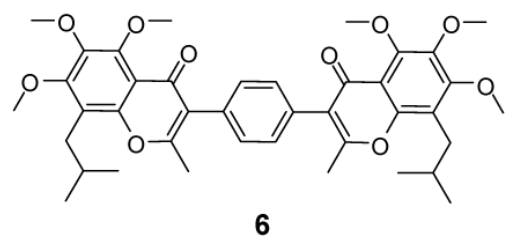

Figure 1.

Structure-based design of flavonoid compounds as a new class of small-molecule inhibitors to target the antiapoptotic Bcl-2 proteins. 

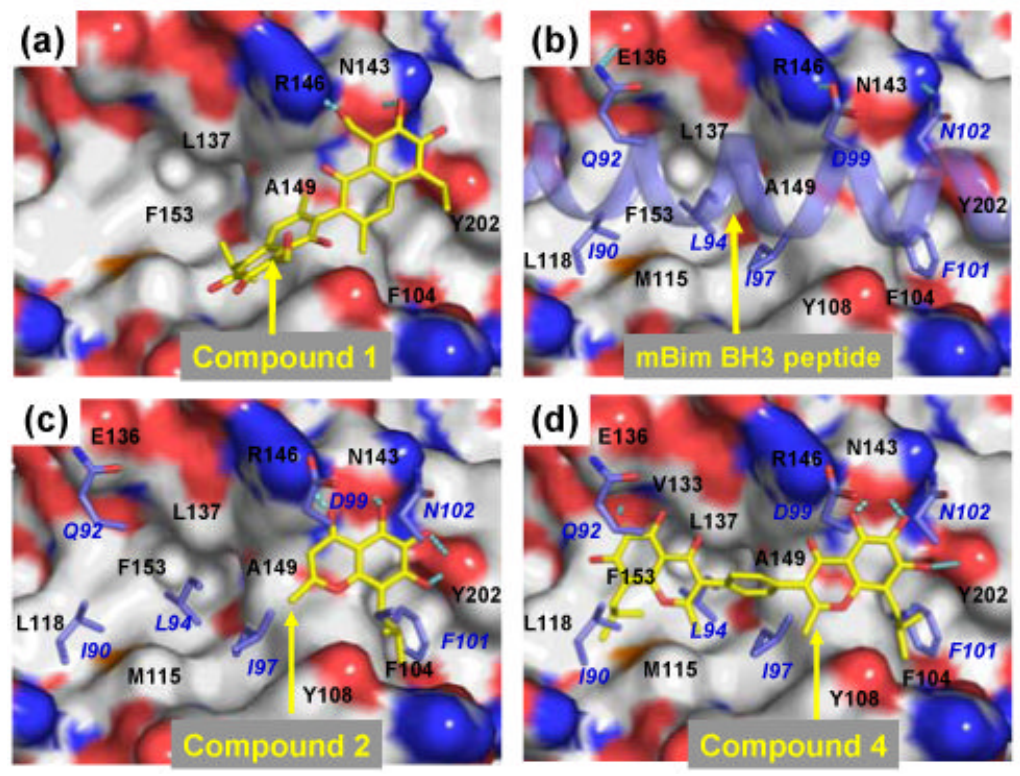

Figure 2.

(a) Predicted binding models of Bcl-2 in complex with (a) compound $\mathbf{1}$; (b) $\mathrm{mBim} \mathrm{BH} 3$ peptide; (c) designed compounds 2 ; and (d) 4 . Bcl-2 is shown in surface representation where carbon, oxygen, nitrogen and sulfur atoms are colored in gray, red, blue and orange respectively. The carbon and oxygen atoms in compounds $\mathbf{1 , 2}$ and $\mathbf{4}$ are shown in yellow and red, respectively. The $\mathrm{mBim} \mathrm{BH} 3$ peptide was shown in a light blue helix. Hydrogen bonds are depicted in dotted lines in cyan. Bim peptide residues are labeled in italic. 


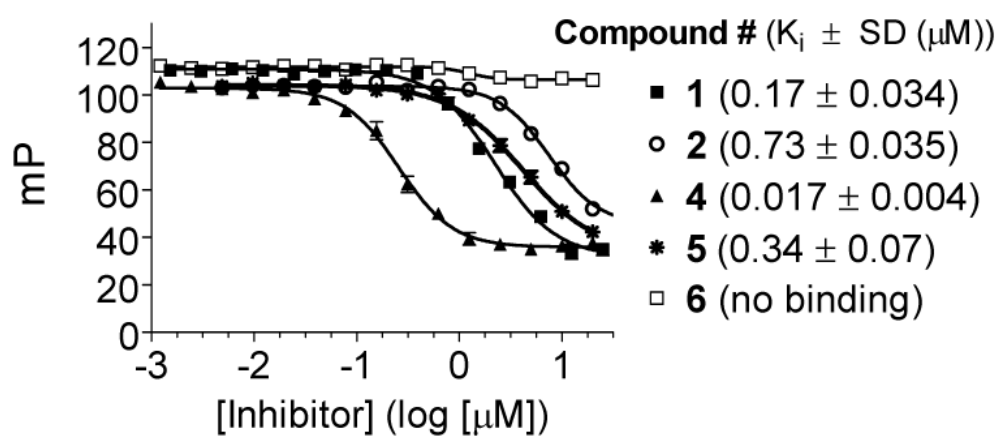

Figure 3.

Competitive binding curves of small-molecule inhibitors to Bcl-2 as determined using a fluorescence-polarization-based binding assay. 


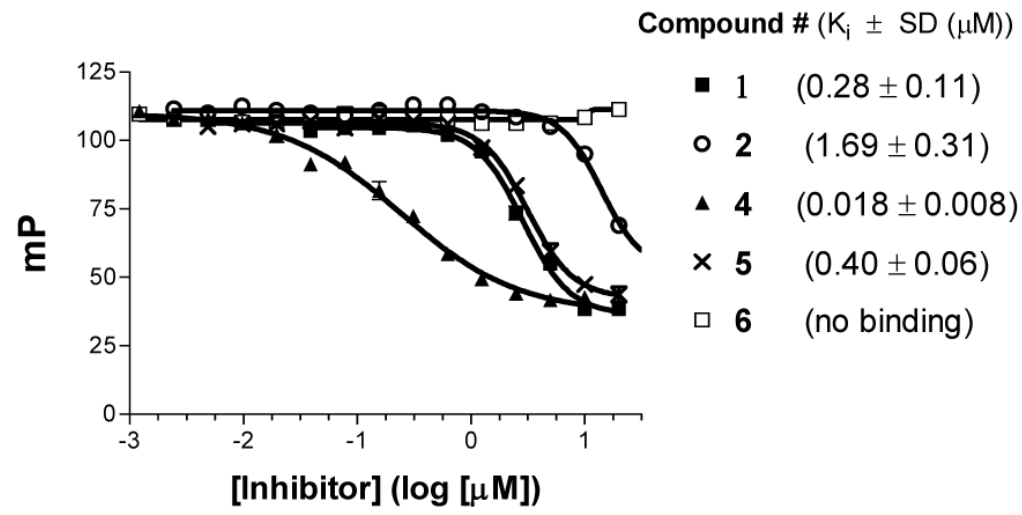

Figure 4.

Competitive binding curves of small-molecule inhibitors to Mcl-1 as determined using a fluorescence-polarization-based binding assay. 


\section{hMcl-1}

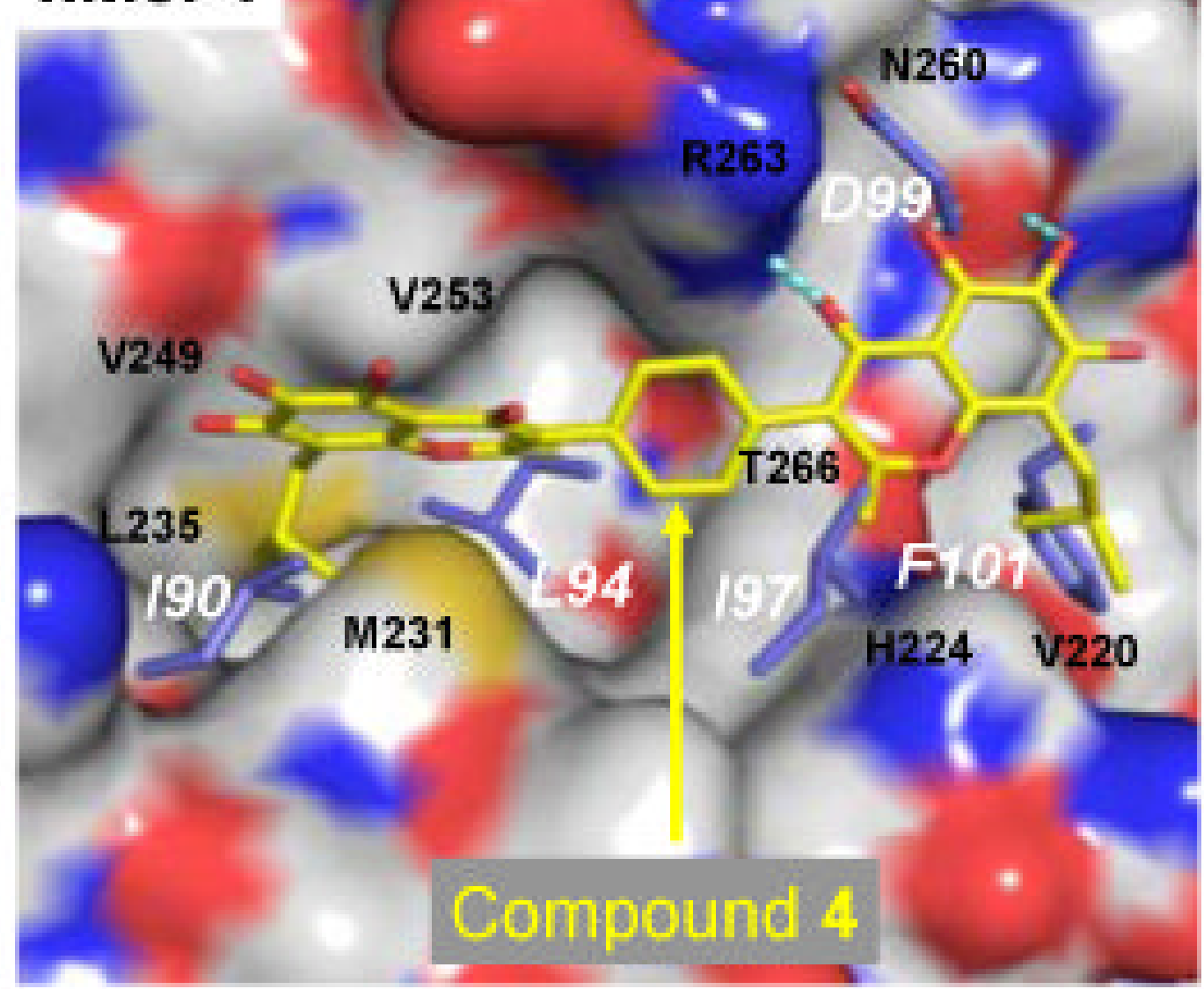

Figure 5.

Predicted binding model of compound 4 with human Mcl-1 obtained after a $1 \mathrm{~ns}$ MD simulation. Residues colored in blue are the superimposed human Bim BH3 peptide. The residue number of the Bim BH3 peptide follows that in the mouse Bim BH3 (I90, L94, I97, D99 and F101), which corresponds to I58, L62, I65, D67, F69 in the human Bim BH3 peptide. 


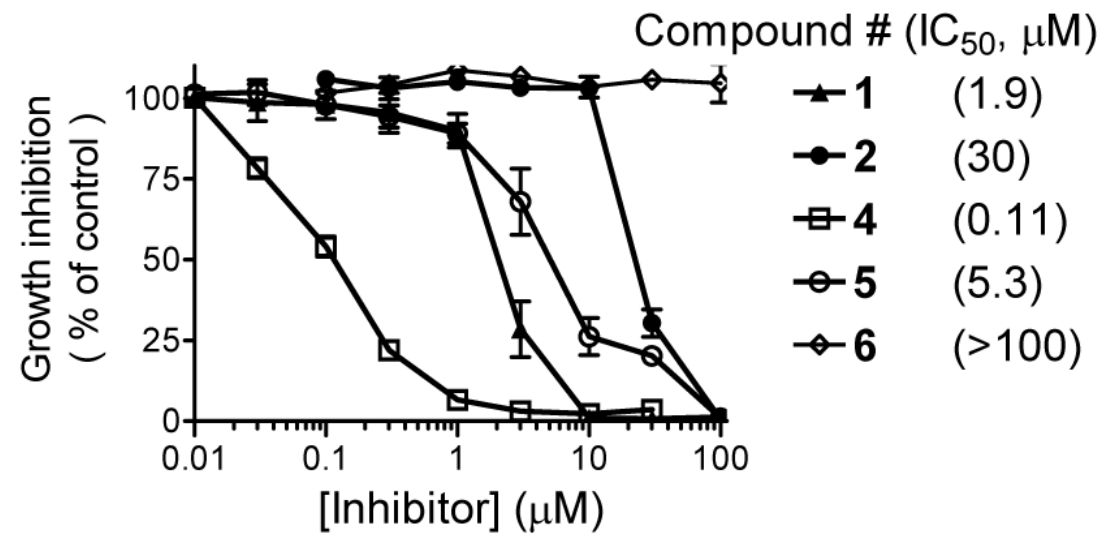

Figure 6.

Inhibition of cell growth by designed small-molecule BH3 mimetics in the MDA-MB-231 (2LMP) breast cancer cell line. Cells were treated for 4 days and cell growth was determined using WST-based assay. 


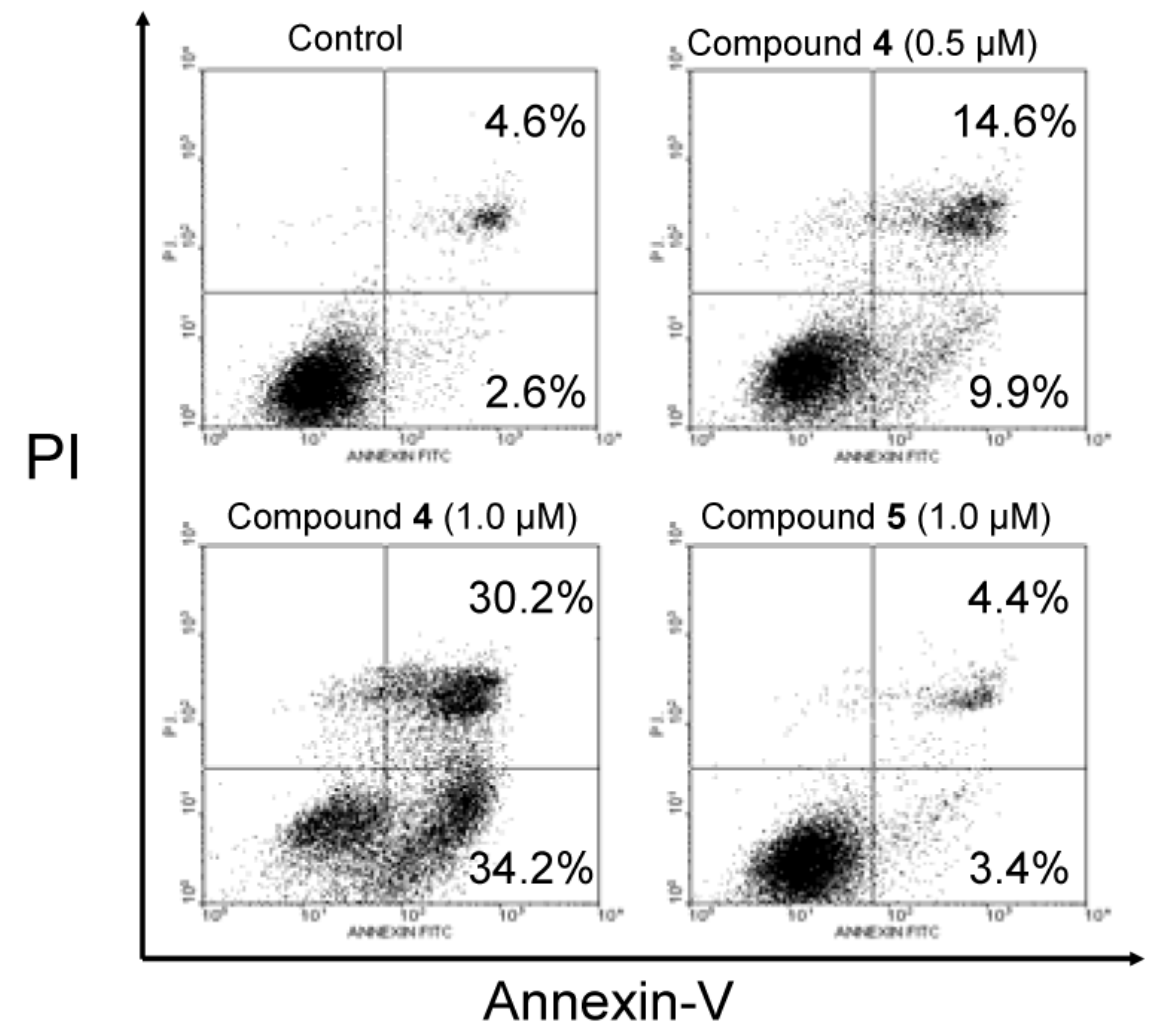

Figure 7.

Analysis of apoptosis induced by compounds $\mathbf{4}$ and $\mathbf{5}$ in the MDA-MB-231 breast cancer cell line. Cells were treated with compounds $\mathbf{4}$ and $\mathbf{5}$ for 3 days and apoptosis was analyzed using Annexin-V and propium iodide (PI) double staining by flow cytometry. Early apoptotic cells were defined as Annexin-V positive/PI-negative, late apoptotic cells as Annexin-V/PI-double positive and necrotic cells as Annexin V positive/PI positive. 


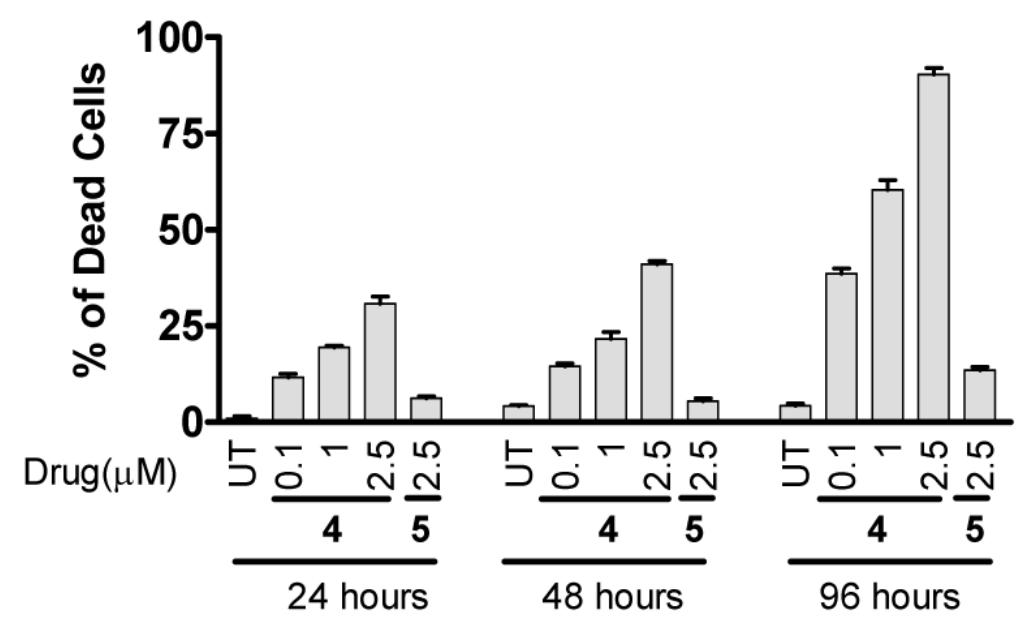

Figure 8.

Cell death induction by compounds 4 and $\mathbf{5}$ in the MDA-MB-231 (2LMP) breast cancer cell line at different time points. Cells were treated by compounds $\mathbf{4}$ and $\mathbf{5}$ for 24, 48 and 96 hours and cell viability was determined using trypan blue exclusion assay. 

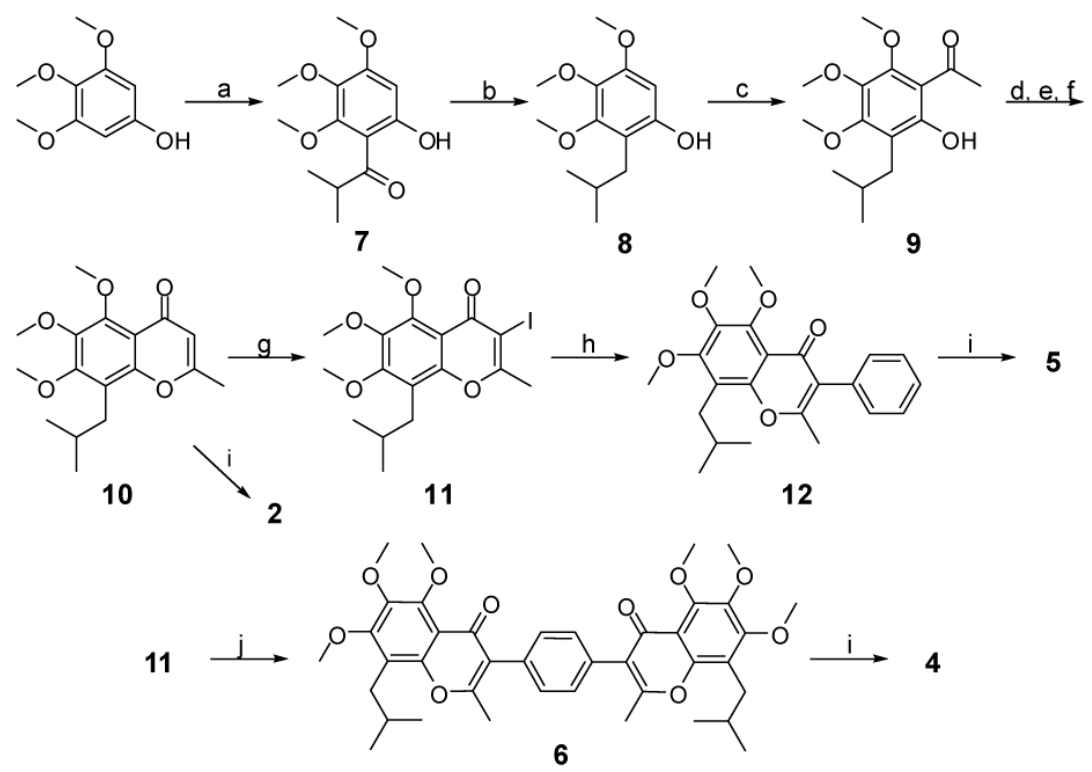

Scheme I.

Synthesis of designed compounds $2,4,5$ and $\mathbf{6}^{\mathrm{a}}$. Reagents and conditions: (a) isobutyric chloride, $\mathrm{BF}_{3} \cdot \mathrm{Et}_{2} \mathrm{O}, \mathrm{Cl}\left(\mathrm{CH}_{2}\right)_{2} \mathrm{Cl}$, reflux, 85\%; (b) $\mathrm{Et}_{3} \mathrm{SiH}$, TFA, 95\%; (c) $\mathrm{AcCl}, \mathrm{BF}_{3} \cdot \mathrm{Et}_{2} \mathrm{O}, \mathrm{Cl}$ $\left(\mathrm{CH}_{2}\right)_{2} \mathrm{Cl}$, reflux, $87 \%$; (d) $\mathrm{Ac}_{2} \mathrm{O}$, pyridine; (e) NaH, DMF; (f) $\mathrm{HCl}, 82 \% \mathrm{f}$ or 3 steps; (g) $\mathrm{I}_{2}$, $\mathrm{CF}_{3} \mathrm{CO}_{2} \mathrm{Ag}, \mathrm{CH}_{2} \mathrm{Cl}_{2}, 0^{\circ} \mathrm{C}, 94 \%$; (h) $\mathrm{PhB}(\mathrm{OH})_{2}, \mathrm{Pd}_{2}$ (dpf $)_{2} \mathrm{Cl}_{2} \cdot \mathrm{CH}_{2} \mathrm{Cl}_{2}, \mathrm{Na}_{2} \mathrm{CO}_{3}$, EtOH, DMF, $\mathrm{H}_{2} \mathrm{O}, 60{ }^{\circ} \mathrm{C}, 92 \%$; (i) $\mathrm{BBr}_{3}, \mathrm{CH}_{2} \mathrm{Cl}_{2},-78{ }^{\circ} \mathrm{C} \sim 0{ }^{\circ} \mathrm{C}$; (j) 1,4-phenylenebisboronic acid (0.5 eq.), $\mathrm{Pd}_{2}(\mathrm{dpf})_{2} \mathrm{Cl}_{2} \cdot \mathrm{CH}_{2} \mathrm{Cl}_{2}, \mathrm{Na}_{2} \mathrm{CO}_{3}$, EtOH, DMF, $\mathrm{H}_{2} \mathrm{O}, 90{ }^{\circ} \mathrm{C}, 96 \%$. 